\title{
PENGARUH PEMBERIAN AIR REBUSAN DAUN JAMBU BIJI (PSIDIUM GUAJAVA LEAF) TERHADAP PERUBAHAN KADAR GLUKOSA DARAH PENDERITA DM TIPE II DENGAN OBESITAS DI WILAYAH KERJA PUSKESMAS JATIBARU KOTA BIMA
}

\author{
${ }^{1}$ Dina Fithriana, ${ }^{2}$ Agus Putradana, ${ }^{3}$ Mukhlishah \\ ${ }^{1,2,3}$ Prodi S1 Keperawatan, Sekolah Tinggi Ilmu Kesehatan (STIKES) Mataram \\ Email Korespondensi: dinafithriana@gmail.com
}

\begin{abstract}
Abstrak. Prevalensi diabetes melitus Tipe 2 dengan obesitas meningkat dengan pesat di seluruh dunia. Semakin besar indeks massa tubuh (IMT) semakin besar risiko menderita diabetes melitus tipe 2. Adapun tujuan dari penelitian ini adalah untuk mengetahui apakah ada pengaruh air rebusan daun jambu biji terhadap kadar glukosa darah penderita DM tipe II dengan obesitas di wilayah kerja Puskesmas Jatibaru Kota Bima. Desain penelitian dalam penelitian ini menggunakan penelitian Quasy experimen one group pre-posttest design. Sampel yang digunakan dalam penelitian adalah penderita diabetes mellitus tipe II dengan obesitas yang rawat jalan Di wilayah kerja Puskesmas Jatibaru Kota Bima sebanyak 40 orang. Tehnik pengambilan sampel yang digunakan porpusive Sampling. Instrumen yang digunakan adalah kuisioner serta analisa data menggunakan wilcoxon. Hasil penelitian menunjukan bahwa Kadar gula darah pasien DM tipe II dengan Obesitas sebelum diberikan Air Rebusan Daun Jambu Biji semua responden dalam kategori buruk 40 responden (100\%) dan setelah diberikan Air Rebusan Daun Jambu Biji sebagian besar dalam kategori kadar gula darah sedang berjumlah 20 responden (50.0).Hal ini juga dapat dilihat dari nilai uji analisa p value lebih kecil dengan taraf signifikan 0,05 didapatkan nilai sig $(2$ tailed $)=0.00$ maka p value $<\alpha$ sehingga Ha di terima dan H0 ditolak yang menunjukan ada pengaruh air rebusan daun jambu biji terhadap kadar glukosa darah penderita DM tipe II dengan obesitas di wilayah kerja Puskesmas Jatibaru Kota Bima. Kesimpulan dalam penelitian ini adalah didapatkan bahwa ada pengaruh air rebusan daun jambu biji terhadap perubahankadar glukosa darah penderita DM tipe II dengan obesitas di wilayah kerja Puskesmas Jatibaru Kota Bima. Saran untuk Responden agar dapat menggunakan terapi rebusan dan jambu biji untuk membatu mengendalikan kadar gula darah pada pasien dengan DM tipe II.
\end{abstract}

Kata kunci : Air rebusan daun jambu biji, glukosa darah dan Penderita DM Tipe II,dan Obesitas

\begin{abstract}
Introduction : The prevalence of Type 2 diabetes mellitus with obesity is increasing rapidly worldwide. The greater the body mass index (BMI), the greater the risk of suffering from type 2 diabetes mellitus. The purpose of this study was to see whether there was an effect of boiled guava leaf water on blood glucose levels of type II diabetes mellitus sufferers with obesity in the working area of Jatibaru Public Health Center, Bima City. Methode : The research design in this study used a Quasy experimental one group pre-posttest design. The sample used in the study was 40 outpatients with type II diabetes mellitus in the working area of Puskesmas Jatibaru Kota Bima. The sampling technique used was porpusive sampling. The instrument used was a questionnaire and data analysis using Wilcoxon.Result : The results showed that the blood glucose levels of type II DM patients before being given boiled water for guava leaves, all respondents were in the bad category of 40 respondents (100\%) and after being given boiled water, most of them were in the category of moderate blood glucose levels, there were 20 respondents (50, 0 This can also be seen from the value of the analysis test value is greater or less with a significant value of 0.05, then the value of $p>\alpha$ so that Ha is accepted and HO is rejected or vice versa. Conclusion: The conclusion in this study is that it is found that the effect of boiled water guava leaves on changes in glucose levels in patients with type II diabetes mellitus with obesity in the working area of Puskesmas Jatibaru Kota Bima.
\end{abstract}

Key words: Guava leaf boiled water, blood glucose, Type II DM and obesity 


\section{PENDAHULUAN}

Prevalensi diabetes melitus Tipe 2 dengan obesitas meningkat dengan pesat di seluruh dunia. Semakin besar indeks massa tubuh (IMT) semakin besar risiko menderita diabetes melitus tipe 2. Hasil penelitian epidemiologis di negara maju menunjukkan bahwa meningkatnya prevalensi obes sejalan dengan meningkatnya prevalensi diabetes melitus tipe 2.Salah satu faktor resiko penyebab terjadinya diabetes tipe II yaitu obesitas. Obesitas merupakan salah satu penyebab resistensi insulin yang akhirnya memicu peningkatan kadar gula darah (Lingga, 2012).

National Diabetes Audit (NDA: 2018 )

Data menunjukkan bahwa di Inggris, 90\% dari orang dewasa dengan tipe 2 diabetes berusia 16-54 tahun mengalami kelebihan berat badan atau obesitas, dibandingkan dengan hanya $10 \%$ yang berat badan yang sehat atau kekurangan berat badan. Selanjutnya berdasarkan pola pertambahan penduduk di Indonesia Tahun 2030 diperkirakan terdapat 12 juta penyandang diabetes di daerah urban dan 8,1 juta di daerah rural. Sementara itu Indonesia merupakan salah satu negara dengan jumlah kejadian obesitas yang besar di dunia dengan jumlah prevalensi obesitas tahun 2001 yaitu berkisar 12,3\%. Pada tahun 2005, prevalensinya meningkat menjadi $12,5 \%$ dan di tahun 2015 berkisar 12,5, dan prevalensinya meningkat pada tahun 2018 berjumlah $21,8 \%$ jumlah obesitas di Indonesia meningkat sangat tinggi. Data tersebut membuktikan bahwa obesitas dan diabetes melitus merupakan masalah kesehatan masyarakat yang serius di Indonesia.

Data Diabetes Melitus tipe 2 dengan obesitas di wilayah kerja puskesmas Jatibaru enam bulan terakhir dari bulan Januari sampai Juli tahun 2020 di peroleh data 45 orang, meningkat dari angka kejadian Diabetes Melitus type 2 pada tahun sebelumnya bulan Juni sampai Desember 2019 yaitu menurut data hanya 20 orang. Kebiasaan masyarakat mengkonsumsi lebih banyak nasi daripada lauk pauk lainya memicu meningkatnya kadar glukosa darah, dan kurangnya kesadaran masyarakat untuk menjaga kesehatan dengan mengkonsumsi makanan sehat lima sempurna.

Masalah utama yang harus diwaspadai seiring dengan peningkatan prevalensinya yaitu terjadinya hiperglikemik atau peningkatan kadar gula darah, selain obatobatan antidiabetes Penggunaan herbal dapat membantu pengendalian penyakit DM Tipe 2 dengan obesitas. Beberapa herbal memiliki aktivitas pengendalian kadar gula darah sekaligus membantu metabolisme lemak. Contohnya, daun jambu biji, yang dapat membantu mengendalikan kadar gula darah dan lemak tubuh.

\section{METODE PENELITIAN}

Desain penelitian yang digunakan dalam penelitian ini adalah penelitian Preeksperimental dengan rancangan "One Group Pretest-postest Design'.'Rancangan ini tidak ada kelompok pembanding (kontrol), tetapi paling tidak sudah dilakukan observasi pertama (pre-test) yang kemungkinan menguji perubahan-perubahan yang terjadi setelah adanya eksperimen (program) (Notoatmodjo, 2010).

Populasi target dalam penelitian ini yaitu penderita diabetes mellitus tipe II dengan obesitas yang rawat jalan di wilayah kerja Puskesmas Jatibaru Kota Bima sebanyak 45 orang.

Sampel dalam penelitian ini adalah penderita diabetes mellitus tipe II yang rawat jalan Di wilayah kerja Puskesmas Jatibaru Kota Bima sebanyak 40 orang yang didapatkan dengan menggunakan teknik sampling purposive sampling yaitu teknik penetapan sampel dengan cara memilih sampel diantara populasi sesuai dengan yang dikehendaki peneliti (tujuan/masalah dalam penelitian) sehingga sampel tersebut dapat mewakili karakteristik populasi yang telah dikenal sebelumnya (Nursalam, 2002).

Kriteria Inklusi sebagai berikut :

1. kadar Glukosa darah sewaktu $<400 \mathrm{mg} / \mathrm{dl}$

2. Obesitas I dan 25,0 - 29,9

3. Mengkonsumsi OHO (obat Hipoglikemik Oral) 
4. Bersedia menandatangani informent consent

\section{Kriteria Eksklusi}

1. Memiliki penyakit jantung

2. Gangguan mental

3. Penyakit komplikasi lainnya. (ginjal, stroke)

4. Penderita tidak mengikuti intervensi sampai selesai (drop out) karena lemas, jika drop out maka responden akan diganti responden yang lain.

Pemberian Air Rebusan Daun Jambu Biji Yaitu suatu perlakuan dengan cara memberikan rebusan air daun jambu biji baik dari 7 lembar daun segar yang direbus dengan air $750 \mathrm{ml}$ hingga menghasilkan sari daun jambu biji, yang diberikan sekali sehari, pada sore hari dengan dosis $250 \mathrm{~mL}$ Diberikan selama 14 hari.

Kadar Glukosa Darah Kadar glukosa darah DM Tipe 2 yang diukur sebelum dan setelah pemberian air rebusan daun jambu biji dalam satuan $\mathrm{mg} / \mathrm{dL}$ yang diharapkan dapat menurunkan atau mendekati batas normal kadar gula darah setelah perlakuan dengan menggunakan alat Glucometer sesuai SOP.

pengaruh pemberian air rebusan daun jambu biji merupakan variabel bebas dan variabel terikat adalah kadar glukosa darah. Analisis yang utama adalah untuk mengetahui adakah pengaruh air rebusan daun jambu biji terhadap kadar glukosa darah pada penderita DM Tipe 2 dengn obesitas di wilayah kerja Puskesmas Jatibaru tahun 2019 dengan menggunakan rumus uji Wilcoxon.

\section{HASIL PENELITIAN}

Hasil penelitian ini telah dilakukan dari tanggal 26 Agustus 2020 sampai dengan tanggal 9 September 2020 di wilayah kerja Puskesmas Jatibaru Kota Bima dengan jumlah responden 40 orang.

\section{Data Umum}

a. Jenis Kelamin

\section{Tabel 1.1 Distribusi Responden}

Berdasarkan Jenis Kelamin

\begin{tabular}{|c|c|c|c|}
\hline No & $\begin{array}{c}\text { Jenis } \\
\text { Kelamin }\end{array}$ & $\begin{array}{c}\text { Jumlah } \\
\text { Responden }\end{array}$ & $\begin{array}{c}\text { Persentase } \\
(\%)\end{array}$ \\
\hline 1 & Laki-laki & 18 & 45.0 \\
\hline 2 & Perempuan & 22 & 55.0 \\
\hline
\end{tabular}

\begin{tabular}{|l|c|c|}
\hline Total & 40 & 100 \\
\hline \multicolumn{2}{|c|}{ Sumber : Data Primer (2020) } \\
Berdasarkan tabel $1.1 \quad$ diata
\end{tabular}
menunjukan bahwa dari 40 responden jumlah responden sebagian besar berjenis kelamin perempuan sebanyak 22 responden $(55.0 \%)$ dan jumlah responden terendah berjenis kelamin laki-laki sebanyak 18 responden $(45.0 \%)$.

b. Umur

\section{Tabel $\quad 1.2$ Distribusi Responden} Berdasarkan Umur

\begin{tabular}{|c|c|c|c|}
\hline No & Umur & $\begin{array}{c}\text { Jumlah } \\
\text { Responden }\end{array}$ & Persentase(\%) \\
\hline 1 & $36-45$ Tahun & 6 & 15.0 \\
\hline 2 & $46-55$ Tahun & 21 & 52.5 \\
\hline 3 & $56-65$ Tahun & 6 & 15.0 \\
\hline 4 & $>65$ Tahun & 7 & 17.5 \\
\hline \multicolumn{2}{|c|}{ Total } & 40 & 100 \\
\hline
\end{tabular}

Sumber : Data Primer (2020)

Berdasarkan tabel 1.2 diatas menunjukan bahwa dari 40 responden jumlah responden sebagian besar dengan umur 46-55 stahun sebanyak 21 reponden $(52.5 \%)$ dan terendah umur 36-45 tahun dan 56-65 sebanyak 6 responden $(15.0 \%)$.

c. Pendidikan

\begin{tabular}{|c|c|c|c|}
\hline \multirow[t]{2}{*}{ Tabel } & 1.3 & Distribusi & Responde \\
\hline & \multicolumn{3}{|c|}{ Berdasarkan Tingkat Pendidikan } \\
\hline No & Pendidikan & $\begin{array}{c}\text { Jumlah } \\
\text { Responden }\end{array}$ & $\begin{array}{c}\text { Presentase } \\
(\%)\end{array}$ \\
\hline 1 & SD & 0 & 0 \\
\hline 2 & SMP & 6 & 15.0 \\
\hline 3 & SMA & 15 & 37.5 \\
\hline 4 & D3 & 3 & 7.5 \\
\hline 5 & Sarjana & 16 & 40.0 \\
\hline & Total & 40 & 100 \\
\hline
\end{tabular}

Sumber: Data Primer (Didapat Dari Kuisioner)

Berdasarkan tabel 1.3 diatas menunjukan bahwa dari 40 responden didapatkanjumlah responden sebagian besar dengan pendidikan sarjana sebanyak 16 responden $(37.0 \%)$, dan jumlah responden terendah dengan pendidikan SD sebanyak 0 responden $(0.0 \%)$.

d. Pekerjaan

\section{Tabel 1.4 Distribusi Responden}

\section{Berdasarkan Pekerjaan}

\begin{tabular}{|c|c|c|c|}
\hline No & Pekerjaan & $\begin{array}{c}\text { Jumlah } \\
\text { Responden }\end{array}$ & $\begin{array}{c}\text { Presentase } \\
(\%)\end{array}$ \\
\hline 1 & Pedagang & 5 & 12.5 \\
\hline
\end{tabular}




\begin{tabular}{|c|c|c|c|}
\hline 2 & PNS & 10 & 25.0 \\
\hline 3 & Swasta & 9 & 22.5 \\
\hline 4 & $\begin{array}{c}\text { Ibu Rumah } \\
\text { Tangga }\end{array}$ & 9 & 22.5 \\
\hline 5 & Pensiun & 5 & 12.5 \\
\hline 6 & Petani & 2 & 5.0 \\
\hline \multicolumn{2}{|c|}{ Total } & 40 & 100 \\
\hline
\end{tabular}

Sumber : Data Primer (Didapat Dari Kuisioner)

Berdasarkan tabel 4.4 diatas menunjukan bahwa dari 40 responden didapatkanjumlah responden sebagian besar dengan pekerjaan PNS sebanyak 10 responden (25.0\%), dan jumlah responden terendah dengan petani sebanyak 2 responden (5.0\%).

\section{Data Khusus}

Data khusus menyajikan hasil penelitian yang menggambarkan tentang identifikasi pengaruh air rebusan daun jambu biji terhadap kadar glukosa darah penderita DM tipe II dengan obesitas di wilayah kerja Puskesmas Jatibaru Kota Bima.

a. IdentifikasiKadar Gula Darah sebelum diberikan Air Rebusan Daun Jambu Biji

Tabel 2.1 Distribusi Frekuensi Responden Berdasarkan Kadar Gula Darah sebelum diberikan Air Rebusan Daun Jambu Biji

\begin{tabular}{|c|c|c|c|}
\hline No & $\begin{array}{c}\text { Kadar } \\
\text { Gula } \\
\text { Darah } \\
\text { Pretest }\end{array}$ & $\begin{array}{c}\text { Jumlah } \\
\text { Responden }\end{array}$ & $\begin{array}{c}\text { Presentase } \\
(\%)\end{array}$ \\
\hline 1 & Baik & 0 & 0.0 \\
\hline 2 & Sedang & 0 & 0.0 \\
\hline 3 & Buruk & 40 & 100.0 \\
\hline \multicolumn{2}{|c|}{ Jumlah } & 40 & 100 \\
\hline
\end{tabular}

Sumber Data : Data Primer (2020)

Berdasarkan tabel 4.5 dapat menunjukan bahwa kadar Gula Darah responden sebelum diberikan Air Rebusan Daun Jambu Biji semua kadar gula darah responden dalam kategori buruk 40 responden $(100 \%)$.

b. Identifikasi Kadar Gula Darah sesudah diberikan Air Rebusan Daun Jambu Biji

Tabel 2.2 Distribusi Frekuensi Responden Berdasarkan Kadar Gula Darah sesudah diberikan Air Rebusan Daun Jambu Biji

\begin{tabular}{|c|c|c|c|}
\hline No & $\begin{array}{c}\text { Kadar } \\
\text { Gula } \\
\text { Darah } \\
\text { Posttest }\end{array}$ & $\begin{array}{c}\text { Jumlah } \\
\text { Responden }\end{array}$ & $\begin{array}{c}\text { Presentase } \\
(\%)\end{array}$ \\
\hline 1 & Baik & 2 & 5.0 \\
\hline 2 & Sedang & 20 & 50.0 \\
\hline 3 & Buruk & 18 & 45.0 \\
\hline \multicolumn{2}{|c|}{ Jumlah } & 40 & 100 \\
\hline
\end{tabular}

Sumber Data : Data Primer

Berdasarkan tabel 2.2 dapat menunjukan bahwa kadar gula darah sesudah diberikan Air Rebusan Daun Jambu Biji sebagian besar dalam kategori sedang berjumlah 20 responden $(50.0 \%)$, buruk 18 responden $(45.0 \%)$ dan terendah kategori baik sebanyak 2 responden $(5.0 \%)$.

c. Analisa pengaruh air rebusan daun jambu biji terhadap kadar glukosa darah penderita DM tipe II dengan obesitas di wilayah kerja Puskesmas Jatibaru Kota Bima

Tabel 2.3 Hasil uji statistik Wilcoxon Signed Ranks Tes

Test Statistics $^{\mathrm{b}}$

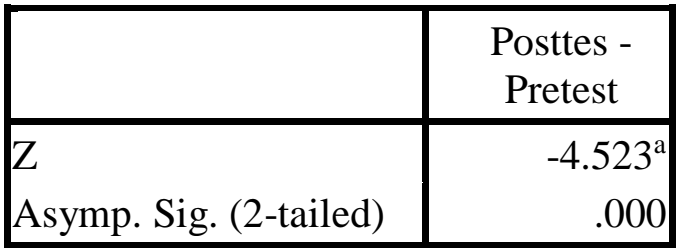

a. Based on positive ranks.

b. Wilcoxon Signed Ranks Test

Berdasarkan tabel 2.3 Berdasarkan hasil uji statstik Wilcoxon Signed Ranks Tes adalah didapatkan nilai sig (2-tailed) $=0.000$ dan $\leq \alpha$ 0.05 maka nilai sig (2-tailed) $<\alpha$ sehingga $\mathrm{Ha}$ diterima dan $\mathrm{H} 0$ ditolak. Hal ini menunjukan ada pengaruh air rebusan daun jambu biji terhadap kadar glukosa darah penderita DM tipe II dengan obesitas di wilayah kerja Puskesmas Jatibaru Kota Bima.

\section{PEMBAHASAN}

Sesuai dengan teori menurut Nurrahmani (2012) dan Wijoyo (2010) mengatakan ada beberapa faktor yang dapat 
mempengaruhi kadar glukosa dara diantaranya kurang sensitifnya jaringan tubuh terhadap insulin karena jumlah atau aktivitas reseptor insulin berkurang pada sel, pola makan yang berlebihan menyebabkan kadar glukosa dalam darah meningkat karena keterbatasan sel $\beta$ pancreas untuk mensekresi insulin, obesitas mengakibatkan lemak yang berlebihan hal ini akan menyebabkan resistensi terhadap insulin, faktor genetic dapat menyebabakan diabetes mellitus karena diwarisinya gen penyebab diabetes mellitus, bahan-bahan kimia dan obatobatan tertentu dapat menyebabkan radang pankreas sehingga pankreas tidak berfungsi secara optimal.

Faktor selanjutnya yang mempengaruhi kadar glukosa darah adalah stress. Stres menyebabkan tubuh menghasilkan hormonhormon racun, kondisi stress yang terus menerus akan menyebabkan terjadi kandungan racun yang melimpah di dalam tubuh. Inilah yang kemudian mengacaukan seluruh metabolism tubuh. Sensitivitas insulin pun terganggu dan menyebabkan terjadinya diabetes mellitus (Susilo, 2011) Sesuai dengan teori yang dikemukakan oleh Anastasia Bangun (2007) pada penelitian kemotaksonomi bahwa dalam daun jambu biji mengandung senyawa tanin yang berfungsi sebagai penghambat $\alpha$ - glukosidase yang bermanfaat untuk menunda absorpsi glukosa setelah makan sehingga menghambat kondisi hiperglikemia postprandial. Kalsium pada daun jambu biji mampu menaikkan produksi sel-sel $\beta$ pankreas untuk menghasilkan insulin. Kalsium bereaksi dengan menstimulus pembebasan insulin dari sel beta pada pulau langerhans pankreas (Simon, 2008).

Pada penelitian sebelumnya Umi Hani (2016) bahwa ada pengaruh yang signifikan pemberian air rebusan daun jambu biji (Psidium guajava) terhadap kadar glukosa darah puasa pada penderita diabetes mellitus tipe II di Desa Leyangan Kec. Ungaran Timur, Kab. Semarang. Mean difference kadar glukosa darah puasa responden kelompok intervensi setelah diberikan air rebusan daun jambu biji (Psidium guajava) sebesar 39,857 mg/dl. dijelaskan bahwa pemberian air rebusan daun jambu biji merupakan suatu metode herbal yang dapat dilakukan untuk pengobatan diabetes mellitus.

\section{Identifikasi Kadar Gula Darah sebelum diberikan Air Rebusan Daun Jambu Biji}

Pada penelitian ini kadar gula darah responden sebelum diberikan Air Rebusan Daun Jambu Biji semua kadar gula darah responden dalam kategori buruk 40 responden $(100 \%)$.

Sesuai dengan teori menurut Nurrahmani(2012) dan Wijoyo (2010) mengatakan ada beberapa faktor yang dapat mempengaruhi kadar glukosa darah diantaranya kurang sensitifnya jaringan tubuh terhadap insulin karena jumlah atau aktivitas reseptor insulin berkurang pada sel, pola makan yang berlebihan menyebabkan kadar glukosa dalam darah meningkat karena keterbatasan sel $\beta$ pancreas untuk mensekresi insulin, obesitas mengakibatkan lemak yang berlebihan hal ini akan menyebabkan resistensi terhadap insulin, faktor genetik dapat menyebabakan diabetes mellitus karena diwarisinya gen penyebab diabetes mellitus, bahan-bahan kimia dan obat-obatan tertentu dapat menyebabkan radang pankreas sehingga pankreas tidak berfungsi secara optimal. Faktor selanjutnya yang mempengaruhi kadar glukosa darah adalah stress. Stres menyebabkan tubuh menghasilkan hormonhormon racun, kondisi stress yang terusmenerus akan menyebabkan terjadi kandungan racun yang melimpah di dalam tubuh. Inilah yang kemudian mengacaukan seluruh metabolisme tubuh. Sensitivitas insulin pun terganggu dan menyebabkan terjadinya diabetes mellitus (Susilo, 2011).

Selanjutnya karena pola makan secara berlebihan dan melebihi jumlah kadar kalori yang dibutuhkan oleh tubuh dapat memacu timbulnya hiperglikemia dan tidak diimbangi oleh sekresi insulin oleh sel $\beta$ pankreas dalam jumlah memadai menyebabkan kadar glukosa dalam darah semakin meningkat dan menyebabkan diabetes mellitus. Penelitian yang dilakukan oleh The Nurses' Health study II terhadap 51.603 wanita usia 22-44, 
ditemukan bahwa peningkatan konsumsi makanan manis dan minuman bersoda membuat berat badan dan risiko diabetes mellitus melambung tinggi. Para peneliti mengatakan, kenaikan risiko itu terjadi karena kandungan pemanis yang terdapat dalam makanan atau minuman bersoda. Selain itu, asupan kalori cair tidak membuat kita kenyany sehingga terdorong untuk minum atau makan lebih banyak (Nurrahmani, 2012)

\section{Identifikasi Kadar Gula Darah sesudah diberikan Air Rebusan Daun Jambu Biji}

Pada penelitian ini kadar gula darah sesudah diberikan Air Rebusan Daun Jambu Biji sebagian besar dalam kategori kadar gula darah sedang berjumlah 20 responden $(50.0 \%)$, buruk 18 responden $(45.0 \%)$ dan terendah kategori baik sebanyak 2 responden $(5.0 \%)$.

Penelitian yang dilakukan Agustiningsih dan Achmad pada tahun 2010 ditemukan kandungan flavonoid dalam daun pandan yaitu sebesar 4,6 mg/dl ekstrak. Dilihat dari jenis kandungan yang sama yang ada pada tanaman lain dan bereaksi sebagai antioksidan dalam mengatasi diabetes mellitus yaitu flavonoid dalam daun sirih merah baru memberikan efek hipoglikemik setelah pemberian ekstrak $20 \mathrm{mg} /$ kilogram berat badan penderita (wijoyo, 2012).

Gambaran kadar glukosa darah setelah intervensi, sebelum-setelah pada penderita diabetes mellitus tipe II di kelurahan Jatibaru Kota Bima mean kadar glukosa darah setelah pemberian terapi air rebusan daun jambu biji (Psidium guajava) sebesar 192,21 mg/dl. Berdasarkan tabel penelitian ini terdapat perbedaan kadar glukosa darah puasa sebelum dan sesudah diberikan air rebusan daun jambu biji (Psidium guajava). Berdasarkan uji t-test dependent didapatkan bahwa p-value 0,000 < $(0,05)$, ini menunjukkan bahwa ada perbedaan yang signifikan kadar glukosa darah puasa sebelum dan sesudah diberikan terapi air rebusan daun jambu biji (Psidium guajava) pada penderita diabetes mellitus tipe II di Kelurahan Jatibaru Kecamatan Asakota Kota Bima.
3. Analisa pengaruh air rebusan daun jambu biji terhadap perubahan kadar glukosa darah penderita DM tipe II dengan obesitas di wilayah kerja Puskesmas Jatibaru Kota Bima

Berdasarkan tabel 2.3 hasil uji statstik Wilcoxon Signed Ranks Tes adalah didapatkan nilai sig (2-tailed) $=0.000$ dan $\leq \alpha 0.05$ maka nilai sig (2-tailed) $<\alpha$ sehingga Ha diterima dan HO ditolak. Hal ini menunjukan ada pengaruh air rebusan daun jambu biji terhadap kadar glukosa darah penderita DM tipe II dengan obesitas di wilayah kerja Puskesmas Jatibaru Kota Bima

Setelah diberikan terapi air rebusan daun jambu biji (Psidium guajava) selama 7 hari, mengalami penurunan kadar glukosa darah perbedaan antara sebelum dan sesudah pemberian air rebusan daun jambu biji pada penderita diabetes mellitus tipe II di puskesmas Jatibaru Kecamatan Asakota Kota Bima. Penurunan ini disebabkan karena kandungan yang terdapat di dalam daun jambu biji yaitu tanin dan kalsium.Tanin adalah zat pahit polifenol yang sangat baik dan cepat mengikat protein.Daun jambu biji (Psidium guajava) adalah herbal yang bermanfaat sebagai penormal fungsi kelenjar pankreas dengan efek farmakologis memperlancar sistem sirkulasi darah dalam membantu menormalkan fungsi pankreasdalam mengatasi diabetes mellitus (Waid, 2011).

Sesuai dengan teori yang dikemukakan oleh Anastasia Bangun (2004) pada penelitian kemotaksonomi bahwa dalam daun jambu biji mengandung senyawa tanin yang berfungsi sebagai penghambat aglukosidase yang bermanfaat untuk menunda absorpsi glukosa setelah makan sehingga menghambat kondisi hiperglikemia postprandial.Kalsium pada daun jambu biji mampu menaikkan produksi sel-sel $\beta$ pankreas untuk menghasilkan insulin.Kalsium bereaksi dengan menstimulus pembebasan insulin dari sel beta pada pulau langerhans pankreas (Simon, 2002).

Hal ini sejalan dengan pernyataan yang mengatakan kandungan yang terdapat di dalam daun jambu biji yaitu tanin dan 
kalsium.Tanin adalah zat pahit polifenol yang sangat baik dan cepat mengikat protein. Daun jambu biji (Psidium guajava) adalah herbal yang bermanfaat sebagai penormal fungsi kelenjar pankreas dengan efek farmakologis memperlancar sistem sirkulasi darah dalam membantu menormalkan fungsi pankreas dalam mengatasi diabetes mellitus, sehingga semakin tinggi /banyak daun jambu biji dapat mempengaruhi kandungan yang terdapat didalamnya (Waid,2011).

\section{KESIMPULAN}

1. Kadar gula darah pasien DM tipe II sebelum diberikan Air Rebusan Daun Jambu Biji semua kadar gula darah responden dalam kategori buruk 40 responden (100\%)..

2. Kadar Gula darah pasien DM tipe II setelah diberikan Air Rebusan Daun Jambu Biji sebagian besar dalam kategori kadar gula darah sedang berjumlah 20 responden (50.0).

3. Berdasarkan hasil uji statstik dengan menggunakan uji Wilcoxon Signed Ranks Tes adalah didapatkan nilai sig (2-tailed) $=0.000$ dan $<\alpha 0.05$ maka nilai sig (2tailed) $<\alpha$ sehingga $\mathrm{Ha}$ diterima dan $\mathrm{H} 0$ ditolak. Hal ini menunjukan ada pengaruh air rebusan daun jambu biji terhadap perubahankadar glukosa darah penderita DM tipe II dengan obesitas di wilayah kerja Puskesmas Jatibaru Kota Bima.

\section{SARAN}

Sesuai dengan penelitian ini maka saran yang dapat disampaikan kepada pihak yang terkait adalah:

1. Bagi Institusi Pelayanan di Puskesmas Jatibaru

Hasil penelitian ini hendaknya dapat dijadikan pertimbangan agar terapi ini digunakan untuk menurunkankadar gula darah. Hal tersebut bertujuan agar petugas kesehatan dalamupaya penurunan gula darah dengan program-program yang membantu masyarakat agar kondisi mereka saat ini lebih baik, dan mampu menekan timbulnya peningkatan kadar gula darah, seperti terapi rebusan daun jambu biji.
2. Bagi responden

Responden agar dapat menggunakan terapi rebusan dan jambu biji untuk membatu menurunkan kadar gula darah

3. Bagi intitusi pendidikan

Dapat dijadikam sebagai upaya untuk tetap mengembangkan dan meningkatkan mutu pembelajaran ilmu keperawatan serta menyediakan referensi yang lebih luas.

4. Bagi peneliti selanjutnya

Perlu ada penelitian lebih lanjut terkait terapi lain yang membantu menurunkan perubahan kadar gula darah, peneliti menyarankan bagi peneliti selanjutnya agar mempertimbangkan alat ukur jumlah responden dan karakteristik responden, agar dapat memenuhi ketentuan dan jumlah responden yang selanjutnya. Dan peneliti selanjutnya agar mengontrol faktor-faktor yang mempengaruhi kadar gula darah.

\section{DAFTAR PUSTAKA}

American Diabetes association. (2015) Diabetes Guidelines Summary Recommendation From NDEI. Pustaka Utama

Dalimartha, dan Adrian F. (2012).Makanan Dan Herbal Untuk Penderita Diabetes Mellitus Dalam KDT. Jakarta: Penebar Swadaya

Deguchi\&Miyazaki (2010) Antihyperglycemic and antihyperlipidemic effects of guava leaf extract. Nutr Metab (Lond). 2010; 7: 9. Published online 2010 Feb 2. doi: 10.1186/1743-7075-79

Deguchi1 et al, 2010 Effects of Extract of Guava Leaves on the Development of Diabetes in the $\mathrm{db} / \mathrm{db}$ Mouse and on the Postprandial Blood Glucose of Human Subject. Yakult Central Institute for Microbiological Research 2) Yakult Honsha Co., Ltd., Department of Development. 
Guyton Dan Hall. (2014) Buku Ajar Fisiologi Kedokteran.Edisi : 12 : Elsevier.

Hadiati, Sri (2015). Bertanam Jambu Biji Di Pekarangan, Jakarta: AgriFlo.

Herliana, Ersi (2013) Diabates Kandas Berkat Herbal, Jakarta: Fmedia

Infodatin, Pusat Data Dan Informasi Kementrian Kesehatan RI, 2014.

Kariadi Hartini. (2009). Diabetes?Siapa Takut!!: Panduan Lengkap Untuk Diabetesi, Keluarganya, Dan Profesional Medis, Bandung: PT Mizan Pustaka

Lingga, Lanny (2012).Bebas Diabetes Tipe-2 Tanpa Obat, Jakarta: PT ArgoMedia Pustaka.

Notoatmojo, Soekidjo, (2002) Metodologi Penelitian Kesehatan, Jakarta: PT Rineka Cipta.

Nursalam (2011), Konsep Dan Penerapan Metodologi Penelitian Ilmu Keperawatan, Jakarta: Salemba Medika.

Perkeni, (2011).Konsesus Pengelolaan Dan Pencegahan Diabetes Mellitus Tipe II Di Indonesia.Jakarta : Perkeni

Shakeera, et al (2011) Antihyperglycemic Dan Potensi Antihyperlipidemic Of Psidium Guajava Pada Tikus Diabetes Aloksan-Induced. Asian Journal of Pharmaceutical dan Clinical Research Vol 6, Suppl 1, 2013 ISSN - 0974-2441 Vol. 4, Edisi 3, 2011

Shen SC et al (2008) Effect of guava (Psidium guajava Linn.) leaf soluble solids on glucose metabolism in type 2 diabetic rats. Pubmed 2008 Nov;22(11):1458-64. doi: $10.1002 /$ ptr. 2476

Simon W. Coppack. (2002). STATS5 Activity In Pancreatic Beta-Cells Influences The Severity of Diabetes In Animals Models Type I And II, Diabetes, 55 (10): 27052712

Siregar, Tahoma. (2009). Hormon Pankreas Dan Obat Antidiabetes. Surakarta: Fak, Far. Ums
Smeltzer, Suzzane C \& Brenda G. Bare (2002). Buku Ajar Keperawatan Medikal Bedah Brunner Dan Suddarth.Jakarta : Penerbit Buku Kedonkteran. EGC.

Soegondo, S. (2009).Penatalaksanaan Diabettes Mellitus.Jakarta : Fakultas Kedokteran Universitas Indonesia.

Sutedjo, (2012), 5 Stretegi Penderita Diabetes Mellitus Berusia Panjang, Yogyakarta: Penerbit Konisius

Tandra, H. (2008). Diabetes.Jakarta : PT Gramedia Pustaka Utama.

Tandra, Hans (2008) Diabetes. Jakarta: PT gramedia

Waid, Abdul. (2011). Dahsyatnya Khasiat Daun-Daun Obat Di Sekitar Pekarangan. Yogyakarta: Laksana

Waspadji, S., dkk.(2004). Pedoman Diet Diabetes Mellitus.Jakarta : Balai Penerbit Fakultas Kedokteran Universitas Indonesia.

Wijayakusuma, Hembing, (2008) Bebas Diabetes Mellitus Ala Hembing, Jakarta: Puspa Swara 